\title{
Media system of Azerbaijan: current state and problems
}

\section{Introduction}

In the era of formation of information society, the perception of the world and processes that occur in it is largely affected by media, as the image of any subject or object began to play much more important role than before. However, "media" is quite ambiguous concept, above all, it is a broadcast channel, built on ideological, emotional and even unconscious expectations of the audience. Secondly, media is not just a mean of information transmission, it is a certain environment, where cultural codes are produced and broadcasted.

Different types of media, inherent to a particular society influence minds of its users, capturing society in its media package, within which the researcher can identify different cultural schemes and values that form the basis of any society.

Specifics of media include regular informing of large and geographically dispersed audience (of all ages, gender, social status, etc.), which enables almost simultaneous consumption of information, that is indirect and at some extent stereotyped.

Huge opportunities of active influence of media on political consciousness and behavior of citizens demonstrates the crucial role of the "fourth power" in modern society. Some researchers of mass communications mention the coming era of "mediacracy" - power of media that constructs reality by its own rules and discretion rather than reflects and interprets it ${ }^{1}$.

Of course, legally media is not a "continuation" of representative government. Making binding decisions of political or economic nature is not the specifics and strength of the "fourth power". Its strength - spiritual and ideological influence on creation of public consciousness and direction of will arising from the state of public consciousness, public opinion and its ideological content ${ }^{2}$.

1 С. І. Даниленко, Громадянський вимір комунікаційної революиій: модернізація суспільних комунікацій від друкарського верстата до соціальних мереж, Київ 2010.

2 О. Д. Кузнецова, Засоби масової комунікації, Львів : ПАЮ 2005. 
The aim of this work is to study the current state and prospects of development of media system in Azerbaijan.

Mass media in Azerbaijan is mostly state-owned, its material is largely aimed at political influence. This applies particularly to television, which is a major source of information in Azerbaijan.

State control is manifested in the prevalence of public channels and in the state's role in appointment of members and funding of the National Television and Radio Council (NTRC) of Azerbaijan, which issues broadcasting licenses. NTRC of Azerbaijan was established by decree № 794 of the President of Azerbaijan Republic dated October 5, 2002 to ensure the implementation and regulation of state policy in broadcasting sector. The objective of the Council is to regulate the activity of television and radio companies, protect interests of the public during the broadcast, and control the observance of legislation on broadcasting.

The Constitution of Azerbaijan contains articles that define the basic principles of media in the country and guarantee freedom of expression and the right to free information exchange ${ }^{3}$. The Principle Law of Azerbaijan demands that Parliament creates a broad field for media activity. Besides the Constitution, the following Laws of Azerbaijan Republic form the media legislative base: Laws "On mass media"4, "On television and radio broadcasting"5, "On public television and radio broadcasting"6 , and number of other regulations.

The processes of both public and scientific and technical nature - globalization, democratization, information - specify the need for legal regulation of issues concerning openness of the state political power, human right to information, protection of personalized data, priorities for media upon receipt of socially important information, and criminal liability for breach of mentioned legal relations.

The Law "On television and radio broadcasting" includes antitrust restrictions. Each founder has the right to own only one broadcasting organization that may have no more than two television and three radio programs. Broadcasting is done on the basis of special permit (license), issued according to contest's results for a period of 6 years. This period can be extended for another 6 years upon application of the broadcaster. In case of violation of license conditions or other requirements of the law, broadcasting can be stopped from 1 to 7 days by the decision of a court. The court also has the right to revoke the license if it is proved that: broadcasting company provided knowingly false information in order to receive a license; has not started broadcasting within

3 Конституція Азербайджанської Республіки - http://ru.president.az/azerbaijan/constitution, accessed $1^{\text {st }}$ December 2016.

4 Закон Азербайджану «Про засоби масової інформації» -http://www.azerbaijan.az/portal/ Society/MassMedia/massMedia_01_r.html, accessed 1 ${ }^{\text {st }}$ December 2016.

5 Закон Азербайджану «Про телерадіомовлення» - http://online.zakon.kz/Document/?doc_ id=30613517, accessed $1^{\text {st }}$ December 2016.

6 Закон Азербайджану «Про суспільне телерадіомовлення» - http://pandia.ru/text/77/434/1326. php, accessed $1^{\text {st }}$ December 2016. 
6 months after the license has been obtained; spoke in support of public calls for the violent overthrow of state system, the assassination attempt on the integrity and security of the country, incitement to ethnic, racial and religious hatred, riots and terrorism.

However, the main divergence between journalism organizations and legislators was provoked by unclear position on the National Television and Radio Council (NTRC), causing different interpretations in court cases against the media. After entry into force of the Law "On television and radio broadcasting", the presidential decree was issued approving the "Regulation on the National Television and Radio Council", which states that the Council is established to implement the state policy in the field of broadcasting. Its tasks include preparation of the concept of common information space in television and radio spheres, determination of technical and quality standards of broadcasting, holding competitions, license issuance etc. NTRC consists of 9 members appointed by the President of Azerbaijan Republic for the period of 6 years. However, President can not dismiss members of the Council at his own discretion. In September 2004 the Law "On public television and radio broadcasting" came into force, whereby the public broadcaster has the status of an independent legal entity, and can determine the form and content of broadcasts. The state provides it with free and perpetual license and broadcast frequency. The Law defines the sources of funding of public broadcasting company: sponsorship, donations from individuals and legal entities, revenues from advertising, sales programs, and other products, other sources not prohibited by law.

In 1998 Azerbaijan adopted a Law "On information", which comprehensively reviews issues of information, informatization and information protection, and created a legal framework for regulation of information resources, processes, systems and technologies. The Law is the regulation of rights of citizens to receive information, based on the principles of a democratic legal state. It points out that all state and local self-government bodies should ensure the use of Internet resources, and create own web resources? ${ }^{7}$.

Law of Azerbaijan "On mass media" establishes general rules for the search, obtaining, preparation, transmission, production and distribution of media in the country, as well as organizational, legal and economic framework for the press, news agencies, television and radio organizations.

General concepts of mass information and mass media are specified in the Law of Azerbaijan "On mass media", namely in Article 3, according to which "the mass information is foreseen for shareware print, audio-, audiovisual messages and other information, seeking, getting, preparing, transmission, production and distribution of which is not confined to the legislation of the Azerbaijan Republic".

Therefore, if guided by these provisions, any public page on the Internet is a mean of public information, and the information contained on Internet page is media. How-

Закон Азербайджану «Про інформацію» - http://www.wipo.int/wipolex/ru/details.jsp?id=9203, accessed $1^{\text {st }}$ December 2016 
ever, Internet gives everybody the possibility to receive such page. So, there is a need to resolve an issue of the status of the person who publishes information on Internet pages, and the need for state registration of Internet page or other resource on the Internet as a media.

The censorship of media was abolished by Special Decree of President Heydar Aliyev on August 6, 1998. . On July 31, 2008 Decree of President Ilham Aliyev "The concept of state support of media development in Azerbaijan" was approved?

In Azerbaijan, there is no separate regulation governing the activity of online media. Article 3 of the "The basic concepts" of the Law "On mass media" indicates that the Internet is a form of media. Therefore, all legislation on the rights and responsibilities of the media is directly related to the Internet. However, until recently, some government bodies, such as NTRC, expressed the need for adopting a special law on the Internet that was perceived by public as an attempt to limit the activity of online media.

There is also a media self-regulatory body in Azerbaijan called the Press Council, which was established on March 15, 2003 at the first Congress of Journalists. It includes 190 leading news agencies, newspapers, magazines and journalistic organizations of the country ${ }^{10}$. Press Council was registered with the Ministry of Justice of Azerbaijan in April of the same year. The objectives of the Press Council are to implement professional activity of journalists in accordance with legal requirements and professional principles, to conduct public control, to strengthen relations among state authorities, public, and press, to create broad opportunities of freedom of speech, thought and information. Press Council, in accordance with its Charter, implements various training projects for journalists, supports the increase of professional specialization. Press Council of Azerbaijan is a member of World Association of Press Councils and Alliance of Independent Press Councils of Europe, is in close relationship with reputable media organizations of the post-Soviet countries and Turkey. In addition, the organization also cooperates with Press Councils of Austria, Great Britain and India.

There are the following components in media of Azerbaijan: television, print media, radio, online media and news agencies.

\section{Television}

Currently 23 TV channels are broadcasted in Azerbaijan, 9 of which (AzTV, Medeniyyet, İdman Azerbaycan, ITV, Lider TV, ATV, Space TV and ANS TV) are republican and cover most territory of the country. AzTV programs cover $99.9 \%$ of the population, ITV $-88,8 \%$, and other channels - about $80 \%$. According to the agreement with

8 Iсторична справка - http://lib.aliyev-heritage.org/ru/4148127.html, accessed $1^{\text {st }}$ December 2016.

9 «Концепція з підтримки засобів масової інформації Азербайджанської Республіки» - azertag. az/ru/xeber/china-689121, accessed $1^{\text {st }}$ December 2016.

10 Press Council: Azerbaijan - https://accountablejournalism.org/?/press-councils/Azerbaijan, accessed $1^{\text {st }}$ December 2016. 
Republic of Turkey, Turkish TRT-1 channel is also broadcasted in republican format and covers around $95 \%$ of the population.

Besides republican channels, there are also 14 regional channels: Mingechevir TV (broadcast in Mingachevir region), Turkel TV (Ganja-Tovuz) Kepez TV (Ganja), ELTV (Yevlakh), Kanal-S (Shaki), Cenub TV (Lankaran), RTV (Khachmaz), Aygun TV (Zagatala), Alternativ TV (Ganja), Qutb TV (Guba), Xayal TV (Guba), Dunya TV (Sumgait), 2 channels function in Nakhchivan AR - NMR TV (Nakhtechivan State Television and Radio Broadcasting Committee) and Channel 35 TV. In addition, ATVINT channel, owned by independent broadcasting company "Azad Azerbaijan", is broadcasted in order to provide information about Azerbaijan in foreign languages in neighboring and other countries ${ }^{11}$.

The Ministry of Communications and High Technologies of Azerbaijan is the central executive body that carries out state policy and regulates communication sector (telecommunications and post) and high technology. According to Ministry information, broadcasting in the country is carried out with the help of 400 transmitters of different capacities, installed on 224 radio and television stations ${ }^{12}$.

Public Television of Azerbaijan (Ictimai TV) is broadcasted since August, 2005. Its creation was a requirement of the Council of Europe and the condition of membership. Public broadcasting activities are regulated by the Law of Azerbaijan "On Public Broadcasting". The channel is broadcasted 24 hours throughout the country ${ }^{13}$. According to the report of the Institute for Reporters` Freedom and Safety, news that are broadcasted are based not on importance, significance and relevance, but rather on political rating in the country. News always begin with decrees, receptions and visits of the president. Information about authorities is always either positive or neutral, lacking critical views, social and other problems. In general, the information is presented one-sided, much attention is given to the coverage of political parties and associations ${ }^{14}$.

AzTv is the main state information TV channel in Azerbaijan. Azerbaijan State Television and Radio Company is a public institution that was established in 1955, it's Head is appointed by presidential decree. It is the only TV channel in the country that transmits programs throughout the whole country. In addition, TV programs are broadcasted in Russian and English languages ${ }^{15}$. Besides first and second public TV channels, Azad TV International is also multilingual. Formally, it belongs to a private

11 Телерадиовещание // Министерство связи и высоких технологий Азербайджанской Республики: http://www.mincom.gov.az/page-411/page-457/, accessed $1^{\text {st }}$ December 2016.

12 Положение // Министерство связи и высоких технологий Азербайджанской Республики http://www.mincom.gov.az/nazirlik-ru-RU/page-418/\#content_anchor, accessed $2^{\text {nd }}$ December 2016.

13 Телевидение Азербайджана - http://www.azerbaijans.com/content_750_ru.html, accessed $2^{\text {nd }}$ December 2016.

14 Preliminary Report on Media Coverage prior to the 26 September Constitutional Referendum https://www.mediasupport.org/wp-content/uploads/2016/10/AZ-Referendum_MM-report_final. pdf, accessed $2^{\text {nd }}$ December 2016.

15 Офіційний сайт телеканалу AzTv - www.aztv.az, accessed 2 $2^{\text {nd }}$ December 2016. 
group, but in fact it acts in agreement with the Azerbaijani government. Broadcasting is done in Azerbaijani, Farsi, English, Russian and Armenian languages. Its news releases (made by Euronews model without presenters - only video) are about events in Azerbaijan and contain some interesting and sharp off-screen comments on the geopolitical situation in the region. However, the channel always complies with the policy of the Ministry of Foreign Affairs of Azerbaijan, and its sharpness is achieved by the ability of Azad TV International to argue in the interests of Azerbaijan, boldly accusing neighbors - thoughts of the Ministry of Foreign Affairs of Azerbaijan are "voiced". Programs usually criticize the politics of neighboring Armenia. Azad TV International news are much more dynamic than long and pompous program of AzTV and Ictimai TV. In the pauses between multilingual news block, western movies in English, as well as cultural programs in Azerbaijani are broadcasted on the channel.

The introduction of new digital technologies in the field of broadcasting led to the need to replace the analog standard with more modern digital solution. Ministry of Communications and High Technologies of Azerbaijan works on transition to digital television broadcasting for already several years. By December 20, 2016 all regions of Azerbaijan switched to digital broadcasting ${ }^{16}$.

The low level of pluralism, a small number of analytical and political broadcasts, lack of sharp debates characterize Azerbaijani TV channels. In terms of politics, all TV channels without exception demonstrate their loyalty to the government.

\section{Print media}

Although print media is more pluralist, its level of coverage is limited, especially if to compare with TV coverage, most of print media is also loyal to the government. Experts estimate that $80 \%$ of newspapers are public.

Today there are more than 4,500 print media outlets registered in Azerbaijan. However, the actual number of newspapers and magazines that are published with regular intervals, is about 300 , the same as 10 years ago ${ }^{17}$.

Around 80 regional newspapers are print editions of local executive authorities. In most cases, they are published no more than twice a month with a circulation of 500 copies. So it is not possible to talk about the important role of regional press. Although it is worth noting that in three cities of the Republic (Yevlakh, Minghechevir, and Massali) fairly large weekly newspapers are published with a circulation of 3 to 5 thousand copies. Newspaper in Yevlakh exists with the support from local authorities, the other two - from grants and limited advertising revenues.

Another category of newspapers - department or trade editions, which are distributed mainly by subscription. Today they are over 30 of them in Azerbaijan. The

16 Восемь районов Азербайджана перешли на цифровое вещание - http://mediasat. info/2016/12/01/azer-cyfra-tv/, accessed $2^{\text {nd }}$ December 2016.

17 Print Media in Armenia and Azerbaijan - http://www.publicdialogues.info/en/Virtual\%20parallels/ print-media-in-armenia-and-azerbaijan, accessed $2^{\text {nd }}$ December 2016. 
economic situation of these newspapers that are published 2-4 times a month is stable, since they are supported by government agencies and enterprises that directly allocate funds to them or arrange subscription. In some cases, circulation of such newspapers exceeds 20 thousand copies.

All national publications in Azerbaijan (approximately 150 titles) are concentrated in Baku. The only newspaper that is issued seven times a week, is "Yeni Musavat", which has the highest circulation among socio-political publications of the country - about 15 thousand. Another 32 newspapers are also included in the category of daily, they are published 5-6 times a week, and their circulation ranges from 1,000 to 8,500 copies.

Newspapers are divided into independent, party and government. Office of the President is a co-founder of two socio-political publications, the Parliament and the Cabinet of one each. There are not so many party newspapers, and they are not popular among population. Most independent publications can be called in such a way only relatively.

Government newspapers differ in content and form. The most striking examples of government newspapers are "Azerbaycan", "Xalq qəzeti", and "Respublika". These newspapers mainly cover their costs through advertising and subscribers.

Most popular newspapers in Azerbaijan are:

- "Azadliq" ("Freedom") - a daily newspaper;

- "Echo" - an independent socio-political newspaper;

- "Ekspress" - weekly newspaper;

- "Yeni Azerbaycan" ("New Azerbaijan") - a daily newspaper;

- "Yeni Musavat" ("The new Equality") - in Azerbaijani language;

- "525ci Gazet" - daily newspaper;

- "Zerkalo" - daily newspaper.

If to choose out of this list, the most widespread and popular newspapers are "Azerbaycan" and "525ci Gazet".

" $525 \mathrm{ci}$ Gazet" is an independent newspaper, where mostly news about meetings of state leaders, recent events, and legislative proposals are published.

There is also a lot of press in English language in Azerbaijan: "Azerbaijan Today", "AzerNews", "Baku weekly", "Baku Today", and so on. In these newspapers the same news are published, but in English.

Besides newspapers, a lot of magazines are registered in Azerbaijan, but of every two registered magazines (there are more than hundred of them) only one is published. Magazines have limited, but constant readers. Certainty of audience and high quality of printing attract advertisers, by which they mostly exist. Most of magazines are specialized (for women, political, automotive, historical, fashion, for men).

Only newspapers "Express" and "Zaman" have their own polygraphic base. However, in general there is no lack in production capacity. Nowadays in Baku there are about 25 small and medium-sized printing offices and one state publishing house "Azerbaijan", where the majority of periodicals are printed.

The system of distribution of newspapers and magazines is quite complex. Subscription is a small part of circulation of independent and opposition media. In govern- 
ment media, on the contrary, it reaches up to $80 \%$ of circulation. Five companies deal with the sale of newspapers and magazines. Street trading is widespread. Along with major newspapers, which have their own distribution structures, 10 smaller firms deal with street trading of printing press.

State agencies, municipalities, political parties, civil and other organizations, agencies and businesses, and also citizens who are permanently residing in the territory of the Republic, have the right to establish print media. The permission of the executive body is not needed; it is enough to officially notify them 7 days before the first issue of publication. People serving sentences in prisons, citizens, whose incapacity has been confirmed by the court, parties and associations that have not passed the state registration, or activity of which is prohibited by law, can not become founders of media.

Print media, both state and independent, plays smaller role in the coverage of political events than television. This is primarily due to economic factors: in most newspapers the circulation is relatively small, because of the problem of realization due to the limited purchasing power of the population.

\section{Radio}

Nowadays 12 radio stations are broadcasted on FM band in Azerbaijan (radio Azerbaijan Public Radio, Burc FM, Khazar, Lider FM, Antenn, ANS ChM, Space 104 FM, Azad Azerbaijan, 106 FM, Media-FM, Araz FM). At the same time, 2 radio stations are broadcasted on FM band in Nakhchivan Autonomous Republic (Nakhchivan State Radio, Radio Voice of Nakhchivan). Radio station «Azerbaijan» covers $100 \%$ of the Republic, Public Radio - 93\%, other radio stations - 60-90\%.

In Azerbaijan there are news bureaus or permanent correspondents of Russian, Turkish, Iranian Media:

a) Russia is represented in Azerbaijan by correspondents of Public Russian television, agencies "Intepfaks", "ITAR-TASS", newspaper "Izvestia", "Segodnya", "Literaturnaya gazeta", "Russkiy fermer", "Rabochaya tribuna" "Ogonek". In addition, programs of ORT and RTR TV channels, and several radio stations are broadcasted.

b) In Azerbaijan there are correspondents of Turkish media. TV channel TRT, the newspaper "Milliyet", "Anadolu Agency" have their offices there. TV channels TRT-1 and partly TGRT are fully broadcasted. The newspaper "Zaman" is regularly published with a circulation of 10,000 copies a week, also there is a joint Turkish-Azerbaijani agency. Typically, Turkish journalists are Heads of news bureaus and missions.

c) agency IRNA and Iranian television also have news bureaus in Azerbaijan. Mostly Iranian journalists work there. In the south of the country Iranian television is fully broadcasted. 


\section{Online media}

The development of new media is connected with the development of the Internet. According to the data of International Telecommunication Union, today $61 \%$ of the population have access to the Internet ${ }^{18}$.

Nowadays all news agencies of Azerbaijan work online. Daily editions and a lot of magazines have their websites. There are over 10 Internet TV and Internet radio, their audience is small, but the growth trend persists.

The development of Internet media in the Azerbaijani began in 1996, and electronic versions of newspapers began to appear recently. Until then the network was used for information sharing only in correspondence. The basis of the first Internet media was created by newspapers "Zerkalo" (www.zerkalo.az), "Yeni Musavat" (www. musavat.com). Newspaper "Civil Society" has become the first electronic newspaper of Azerbaijan, its activity began in 1990. "Bakutoday.net" - the first online newspaper in English, which began its activity in the 2000s.

Information Agency "Turan" is also considered to be one of the founders of information spreading through the Internet: www.turan.az. Later webpages of newspapers "Azadliq" (www.azadliq.az), "525ci Gazet" (www.525ci.com), "Ayna" (www.ayna. az), "Byzym ESC" (http: // bizimasr .media-az.com /), "Azerbaijan" (http://www.azerbaijan-news.az/), "Zaman" (www.zaman.com.az), and Information Agency "Trend" (www.trend- az.com) were created.

If in 2009 their total audience was 200-300 thousand visitors a month, today only one online-version of the newspaper "Yeni Musavat» has this number of visitors. Over the same period the number of blogs in the country increased from 200 to 5000 . Due to the absence of freedom in traditional media, blogs became a place of commenting political events, and YouTube - a place where you can watch mass protests and rallies. Among online media, the following can be related to opposition media: Internet portals "milli.az" and "Turan", as well as newspapers "Yeni Musavat", "Azadliq", and "Khural".

At the same time there are problems that hinder the development of online media. Despite the significant decline in prices, the Internet in Azerbaijan is several times more expensive than in neighboring Georgia, Turkey and Russia. Users complain about low speed, difficulty with Internet access in regions; representatives of new media - about the weak development of advertising market, technical and technological difficulties.

However, the electronic media is under strict government control. In particular, Law "On amendments to the Criminal Code of Azerbaijan Republic", signed by President of Azerbaijan Ilham Aliyev, which was adopted by Parliament on 14 May 2013 and entered into force on 5 June 2014, aims at strengthening control over the activities of Internet media.

Amendments to the Criminal Code provide criminal responsibility for libel and insults, that are spread in the global network. According to amendments, those who

$1861 \%$ of Azerbaijan population use internet - https://report.az/en/ict/61-of-population-use-internetin-azerbaijan/, accessed $2^{\text {nd }}$ December 2016. 
allow themselves to spread slander on the Internet, can receive a 100 - 500 manat fine and 240 hours of community service, a year of corrective labor or six months in prison. Punishment for Internet insulting is quite bigger. Thus, Internet users, especially of Facebook and other social networks, community portals can also be brought to criminal responsibility, as well as journalists ${ }^{19}$.

Human rights organizations claim that in Azerbaijan the fabricated charges are frequently used for detention of journalists. According to the latest data, the official list of imprisoned journalists and bloggers include bloggers Abdul Abilov and Rashad Ramazanov, journalists Seymur Hezi, Araz Guliyev, Nijat Aliyev and Fikret Feremezo$\mathrm{glu}^{20}$. In fact, this number could be much higher.

On May 25, 2016 experts of UN working group on arbitrary detention claimed that in Azerbaijan criminal prosecution has been transformed "into a tool with the aim to silence human rights defenders, journalists and political opponents"21.

Azerbaijani human rights activists and journalists claim that adopted amendments contradict international obligations of Azerbaijan in the field of freedom of expression, particularly in the Internet.

Given that until recently Internet remained almost the only platform for expressing opposition views, the aforementioned changes to the Criminal Code can lead to further deterioration of media sustainability index in Azerbaijan.

5. Information agencies

Azertac (Azerbaijan State Telegraph Agency) is the biggest information agency. Created by the Government of the Azerbaijan Democratic Republic on March 1, 1920, Azertac operated under different names in Soviet times. The first name was Azerbaijan Telegraph Agency, then - Azerinform (Azerinform). As a result, when Azerbaijan became independent again, the agency has resumed its historic name.

Nowadays Azertac, along with the official state news, continues to disseminate information about social, political and economic issues, science, education, culture, health, sport, environment and others. It is broadcasted in Azeri, Russian and English languages.

Besides, the following information agencies act in Azerbaijan:

1. Azeri Press Agency (APA)

2. "Azer press" Information Agency

3. "Azmedia" Analytical Information Agency

4. "Azadinform" Information Agency

5. "Assa-irada" Information Agency

6. "Em-pi-ey" Information Agency

19 Кримінальний кодекс Азербайджана - http://online.zakon.kz/Document/?doc_id=304 20353\#pos=1;-263, accessed $2^{\text {nd }}$ December 2016.

20 В обновленный список политзаключенных Азербайджана внесены 119 человек - http://www. kavkaz-uzel.eu/articles/293312/, accessed $2^{\text {nd }}$ December 2016.

21 Эксперты ООН о проблемах судебно-правовой системы Азербайджана -http://www.contact. az/docs/2016/Politics/052500157283ru.htm\#.WFgSg1WLTIU, accessed $3^{\text {rd }}$ December 2016. 
7. "Olaylar" Information Agency

8. "Turan" Information Agency

9. "Trend" Information Agency

10. "İnterfaks-Azerbaijan" Information Agency

11. Müstəqil Information Agency

12. "Ses" Information Agency

13. "Fineko" Information Agency

14. "Riyad media" Information Agency 22.

International broadcasting is one of the most important areas of distribution of foreign policy information. According to the researcher D. Boyd, there are four reasons why the state needs international broadcasting:

- The need to increase the authority of the state on international arena;

- Promotion of national interests;

- Promotion of political, religious ideals;

- Strengthening of cultural ties.

E.Gilboa believes that it is necessary to add one more reason: creation of favorable perception of state's foreign policy in international environment. Today, "when decisive importance is not what people hear, but what they are told", the perception of politics is particularly important. In fact, all these reasons determine the need of particularly careful attention to international broadcasting of the state.

ATV-int (ATV International) is a first international satellite TV channel in Azerbaijan, and is a subsidiary of the independent TV channel ATV (Azad Azerbaijan). Mostly news, various TV shows, and information-analytical programs are broadcasted. Broadcasting is carried out in Azerbaijani, Russian, Farsi, English and Russian languages. Information is selected according to the specifics of language of broadcasting of each of the five editorial offices.

Sputnik is an international news agency and radio with multimedia information hubs in dozens of countries. It consists of websites, analogue and digital broadcasting, mobile applications and social network pages.

Radio Sputnik Azerbaijan is aired on Araz 103,3 FM radio wave. Broadcasting is in Azerbaijani language, includes news on relevant world and regional events that come out 11 times a day.

Information portal Sputnik was launched in May 2015, broadcasting is carried out in Azerbaijani and Russian languages, available at sputnik.az and ru.sputnik.az.

\section{The current state of development}

In Azerbaijan the incompleteness of legal regulation of information security persists. It resulted in unfavorable situation for authorities in information space, which, in turn, generates new challenges and threats to the national security of Azerbaijan in information networks. In particular, these processes are exacerbated during intensive in-

22 Азербайджан - http://www.azerbaijans.com/content_744_ru.html, accessed 3 ${ }^{\text {rd }}$ December 2016. 
ternational information exchange through global social network, which increases the impact of electronic and print media on socio-political and cultural life, and moral state of society.

Despite the fact that Azerbaijan has considerable resources to strengthen its information influence - television, radio, print media, Internet resources - there is no clear understanding of how to use it for creation of positive reputation in the world. This situation is influenced by the fact that Azerbaijan is in conflict with Armenia on Nagorno-Karabakh for many years, which has a negative effect on country's image. Sometimes news from Armenia or representatives of Armenian diaspora in conflict zone come out, and of course, they usually describe the conflict one-sided. There is no reaction from Azerbaijan in most cases, due to the fact that no activity on counterpropaganda of possible negative information flows is carried out.

Officially, this role has to be fulfilled by the Ministry of Communications and High Technologies of Azerbaijan. The Regulation of the Ministry states that its activities include participation in policy-making and implementation in the field of information security, prevention of global cyber attacks, and protection of national electronic information resources. Main functions include developing, regulation of activity, and implementation of a unified state policy in the field of communication and information technologies; encouraging the creation of new forms of social and economic activity by using information technologies, creation of information markets.

In fact, this role was mostly taken by Azerbaijani journalists, who regularly, although sometimes one-sided, track all negative information "emissions", but most part of their counterpropaganda is ineffective, because almost all materials are printed in local media for local readers and barely any materials are printed in world foreign media.

Websites of many ministries and departments usually include information in Azerbaijani language, everything in either English or Russian is mostly advertising, which doesn't provide information for business stakeholders.

Along with undeniable advantages, the Internet also creates new challenges for both individuals and national security in general. Azerbaijan did not take any serious measures to protect its information field, and information security issues were reviewed not separately, but as a part of overall security. Recently the country has faced an urgent need to strengthen the information component of national security, that is why the development of the National Information Security Concept of Azerbaijan is important. This is due to the growing influence on state information security of processes that occur in an international environment with regard to hybrid challenges in political, social and economic life. In addition, Nagorno-Karabakh conflict influences the information security of Azerbaijan. Censorship is s serious factor impeding the development of free independent media. Despite the fact that media censorship was abolished by the Special Decree of President Heydar Aliyev on August 6, 1998, in practice everything is different.

Azerbaijan took the fifth place in rating "10 Most Censored Countries", created by organization "Committee to Protect Journalists". As it states in report, the main source 
of information in Azerbaijan is television and radio companies, which are owned and controlled by state or its proxies. International organizations mostly either have no access to the country or their satellite signals are jammed. Print media that criticizes officials, are subject to harassment by the state, they are debilitated by lawsuits, dislodged of rented premises, have restriction of the use of funds from foreign sources, and their advertisers are forced to refuse from advertising. Authors of Internet publications practice self-censorship, remembering that there is a criminal liability for defamation according to the law, which carries a six-month prison sentence. Information websites and social media network can be blocked at any time at the request of the government. At least 10 journalists and bloggers are serving sentences in Azerbaijani prisons. Several journalists who criticized the government, fled the country in 2014, but those who remained faced attacks and harassment, they were forbidden to leave the country or were prosecuted on fabricated charges ${ }^{23}$. According to research of «Freedom House» in 2016, freedom of the press in Azerbaijan is almost absent, it is rated 89 points out of 100 , where 100 is the worst option. This information was published in the report "Freedom of the press" in 2016. "Freedom of the Press» is the annual research and accompanying rating on the state of media freedom in the world, created by the international non-governmental organization «Freedom House».

In report of "Freedom House" in 2016 it is noted that various cases of violation of the rights and freedoms of journalists and legislation on media activity were recorded. For example, despite the fact that the Azerbaijani government should appoint nine members of the National Television and Radio Council, in 2015 there were only 7 of them. There were cases of repeated criticism by demonstrating bias towards public broadcasters in decisions on licensing, which remain obscure, failure to publish the list of available television and radio frequencies, despite the obligation to do so annually.

In recent years, government increased the volume of its activities in the field of monitoring the Internet activity and persecution of activists, journalists and bloggers. Defenders of media freedom expressed particular concern regarding monitoring of the Internet activity and telephone conversations. While the official blocking of content is relatively rare case in Azerbaijan, the government actively uses intimidation to curb online criticism. It was reported that in 2013 authorities blocked the image-sharing website after documents of state security services were leaked. The independent media, including Azadliq and RFE / RL, reported on recent DDoS attacks ${ }^{24}$.

In Resolution 2062 of the Parliamentary Assembly of the Council of Europe it is noted that the Assembly is deeply concerned about growing number of repression against independent media and supporters of freedom of speech in Azerbaijan. Cases of arbitrary application of criminal legislation to limit freedom of expression of opinion

2310 most censored countries - https://www.cpj.org/2015/04/10-most-censored-countries.php, accessed $3^{\text {rd }}$ December 2016

24 Freedom House - https://freedomhouse.org/report/freedom-press/2016/Azerbaijan, accessed $3^{\text {rd }}$ December 2016. 
were recorded, particularly in recent years various criminal laws against journalists and bloggers are used. The Resolution encourages to take necessary measures to ensure independent and impartial trial in cases, which involve journalists and other people, who express critical thoughts ${ }^{25}$.

Representatives of Organization for Security and Cooperation in Europe (OSCE) have also repeatedly criticized the government of Azerbaijan and expressed outrage regarding violation of human rights and press freedom. In response, Azerbaijan terminated the Memorandum of Understanding on the OSCE Project Co-ordinator in Baku, which caused the closure of OSCE office in Azerbaijan in July 2015 ${ }^{26}$.

Thus, we can conclude that Azerbaijan has considerable resources to strengthen its information influence - television, radio, print media, Internet resources. However, strong state control over the activities of broadcasters in the country has remained. Actual censorship by the state is a deterrent of media development, especially considering that special Order of President Heydar Aliyev on August 6, 1998 abolished the censorship of the media. International organizations and human rights organizations regularly record violations of human rights and freedoms, restrictions on the rights to freely express own opinions, arrests of journalists, bloggers and photographers. Currently it is extremely important for the country to create a basis for the formation of a stable and secure information environment in Azerbaijan, and fulfill necessary conditions for its integration into the global information space. It is necessary to create a clear and urgent legal framework to protect the information environment of the country, and develop effective strategies for its implementation.

\begin{abstract}
This article discusses features of the establishment and functioning of media in Azerbaijan and legal aspects of its activity. In particular, special attention is given to the research of television, print media, radio, online media, information agencies, etc. Key channels of mass media of Azerbaijan, peculiarities and specifics of its activity were analyzed and distinguished. Basic documents, regulating media in Azerbaijan, in particular, laws of Azerbaijan Republic "On mass media", "On television and radio broadcasting", "On public television and radio broadcasting" and number of other regulations were reviewed in details. The activity of regulatory bodies, such as the National Television and Radio Council and the Press Council was analyzed. Conclusions about current trends and challenges of media in Azerbaijan were made based on the analysis, official statistics of international organizations (Freedom House, the Committee to Protect Journalists) on the state of media in Azerbaijan, including the issue of censorship in the country, were presented.
\end{abstract}

Key words: Azerbaijan, media, television, radio, press, online media.

25 The functioning of democratic institutions in Azerbaijan - http://assembly.coe.int/nw/xml/XRef/ Xref-XML2HTML-en.asp?fileid=21953\&lang=en, accessed $3^{\text {rd }}$ December 2016.

26 Azerbaijan Orders OSCE To Close Baku Office - http://www.rferl.org/a/27055923.html, accessed $3^{\text {rd }}$ December 2016. 


\section{System medialny Azerbejdżanu: aktualny stan i problemy}

Streszczenie: W artykule omówiono uwarunkowania tworzenia i funkcjonowania mediów w Azerbejdżanie oraz prawne aspekty ich działalności. Szczególną uwagę poświęcono badaniom nad telewizją, mediami drukowanymi, radiem, mediami internetowymi, agencjami informacyjnymi itp. Przeanalizowano i wyróżniono kluczowe kanały masowego przekazu w Azerbejdżanie i specyfikę ich działania. Przedstawiono akty prawne, regulujące rynek medialny w Azerbejdżanie, w szczególności ustawę Republiki Azerbejdżanu „0 środkach masowego przekazu”, „0 środkach telewizyjnych i radiowych”, „0 publicznej telewizji i radiofonii”. Omówiono działalność organów regulacyjnych, takich jak Krajowa Rada ds. Telewizji i Radia oraz Rada Prasowa. Wnioski dotyczące aktualnych trendów i wyzwań mediów w Azerbejdżanie oparto na analizie oficjalnych statystyk organizacji międzynarodowych (Freedom House, Komitet Ochrony Dziennikarzy) na temat stanu mediów w Azerbejdżanie, w tym kwestii cenzury w kraju.

Słowa kluczowe: Azerbejdżan, media, telewizja, radio, prasa, media internetowe

\section{Медиасистема Азербайджана: текущее состояние и проблемы}

Аннотация: В статье рассматриваются условия создания и функционирования СМИ в Азербайджане, а также правовые аспекты их деятельности. Особое внимание было уделено исследованиям телевидения, печатных СМИ, радио, онлайн-СМИ, информационных агентств и т. д. Были проанализированы и выделены ключевые каналы массовой коммуникации в Азербайджане и особенности их работы. Представлены правовые акты, регулирующие медиарынок в Азербайджане, в частности - Закон Республики Азербайджан «0 средствах массовой информации», «0 телевидении и радио», «Об общественном телевидении и радиовещании». Освещена деятельность регулирующих органов, таких как Национальный совет по телевидению и радиовещанию и Совет по прессе. Выводы, касающиеся текущих тенденций и проблем средств массовой информации в Азербайджане, были основаны на анализе официальной статистики международных организаций (Freedom House, Комитет по защите журналистики) о состоянии средств массовой информации в Азербайджане, включая проблему цензуры в стране.

Ключевые слова: Азербайджан, СМИ, телевидение, радио, пресса, интернет-СМИ.

\section{Bibliography}

10 most censored countries - https://www.cpj.org/2015/04/10-most-censored-countries.php

$61 \%$ of Azerbaijan population use internet - https://report.az/en/ict/61-of-population-use-internet-in-azerbaijan/

Azerbaijan Orders OSCE To Close Baku Office - http://www.rferl.org/a/27055923.html

Freedom House - https://freedomhouse.org/report/freedom-press/2016/Azerbaijan

Preliminary Report on Media Coverage prior to the 26 September Constitutional Referendum - https:// www.mediasupport.org/wp-content/uploads/2016/10/AZ-Referendum_MM-report_final.pdf

Press Council: Azerbaijan - https://accountablejournalism.org/?/press-councils/Azerbaijan

Print Media in Armenia and Azerbaijan - http://www.publicdialogues.info/en/Virtual\%20parallels/ print-media-in-armenia-and-azerbaijan 
Pobrane z czasopisma Wschód Europy http://journals.umes.pl/we

Data: 26/04/2023 12:44:36

104

Serhiy Danylenko, Maryna Grynchuk

The functioning of democratic institutions in Azerbaijan - http://assembly.coe.int/nw/xml/XRef/Xref-

XML2HTML-en.asp?fileid=21953\&lang=en

«Концепція з підтримки засобів масової інформації Азербайджанської Республіки» - azertag.az/

ru/xeber/china-689121

Азербайджан - http://www.azerbaijans.com/content_744_ru.html

В обновленный список политзаключенных Азербайджана внесены 119 человек - http://www. kavkaz-uzel.eu/articles/293312/

Восемь районов Азербайджана перешли на цифровое вещание - http://mediasat.info/2016/12/01/ azer-cyfra-tv/

Громадянський вимір комунікаційної революції: модернізація суспільних комунікацій від друкар-

ського верстата до соціальних мереж : монографія / С. І. Даниленко. - К., 2010. - 312 с. - укр.

Закон Азербайджану «Про засоби масової інформації» -http://www.azerbaijan.az/portal/Society/ MassMedia/massMedia_01_r.html

Закон Азербайджану «Про інформацію» - http://www.wipo.int/wipolex/ru/details.jsp?id=9203

Закон Азербайджану «Про суспільне телерадіомовлення» - http://pandia.ru/text/77/434/1326.php

Закон Азербайджану «Про телерадіомовлення» - http://online.zakon.kz/Document/?doc_id=306 13517

Історична справка - http://lib.aliyev-heritage.org/ru/4148127.html

Конституція Азербайджанської Республіки - http://ru.president.az/azerbaijan/constitution

Кримінальний кодекс Азербайджана - http://online.zakon.kz/Document/?doc_id=30420353\#pos $=1 ;-263$

Кузнецова О. Д. Засоби масової комунікації / О. Д. Кузнецова. - Львів : ПАЮ, 2005. - 200 с.

Офіційний сайт телеканалу AzTv - www.aztv.az

Положение // Министерство связи и высоких технологий Азербайджанской Республики - http:// www.mincom.gov.az/nazirlik-ru-RU/page-418/\#content_anchor

Телевидение Азербайджана - http://www.azerbaijans.com/content_750_ru.html

Телерадиовещание // Министерство связи и высоких технологий Азербайджанской Республики: http://www.mincom.gov.az/page-411/page-457/

Эксперты ООН о проблемах судебно-правовой системы Азербайджана -http://www.contact.az/ docs/2016/Politics/052500157283ru.htm\#.WFgSg1WLTIU 